\title{
A HISTORY AND OVERVIEW OF THE AMERICAN ASSOCIATION OF STRATIGRAPHIC PALYNOLOGISTS (AASP)
}

THOMAS D. DEMCHUK

ConocoPhillips

PO Box 2197

Houston, Texas 77252-2197

U.S.A.

e-mail: thomas.d.demchuk@conocophillips.com

JAMES B. RIDING

British Geological Survey

Kingsley Dunham Centre

Keyworth

Nottingham NG12 5GG

United Kingdom

e-mail: jbri@bgs.ac.uk

\begin{abstract}
The American Association of Stratigraphic Palynologists (AASP) is a relatively small international scientific organization dedicated to the furtherance of palynology. It is based in the U.S.A., but has a global membership. This contribution is a companion paper to a work on the early history (1967-1970) of the organization. The Association was born as a direct result of the rapid expansion of stratigraphic palynology in the oil industry, but then and now it has embraced all applications of organic microfossils and their modern counterparts. Following the inaugural meeting AASP had a membership of around 40; it now stands at just over 500. The maximum membership was approximately 1000 in 1987 . AASP collaborates with other scientific bodies and has an extensive range of publications. The Association runs a comprehensive and widely-perused website, organises annual meetings, and gives several types of awards to deserving professional and student palynologists. The most ambitious project of the Association was the establishment of The AASP Center for Excellence in Palynology (CENEX) at Louisiana State University. For a small independent society, AASP has achieved much in its short history and has attained its stated intentions of promoting the science of palynology beyond it's expectations.
\end{abstract}

Key words: AASP; history; palynology; scientific association.

\section{INTRODUCTION}

During the mid to late 1950s and the 1960s, the use of stratigraphic palynology by the oil and gas industry expanded significantly. It was realized at this time that, as a result of their rapid evolution, robustness, and relative ubiquity, palynomorphs had huge local and regional biostratigraphic potential and significance. The possibility of their intercontinental correlation potential was understood somewhat later.

Throughout the 1950s and into the 1960s, pollen and spores were used by 
industrial palynologists and were the 'workhorse' palynomorphs of that era. By that time, the study of pollen and spores was well established. This therefore represented the first stage in the evolution of industrial palynology. However, although useful in some aspects of marine palynology, pollen and spores alone are not capable of solving the complex and varied stratigraphic problems faced by industry (Powell and Riding, 2005). Neither would pollen and spores by themselves have fostered the large numbers of palynological positions in industry that were established during the late 1960s, 1970s, and 1980s. Despite the pioneering paper on reef-controlled distribution of acritarchs ('hystrichospheres') by Staplin (1961), the detailed understanding of the major marine palynomorph groups of acritarchs and dinoflagellate cysts awaited the landmark research by David Wall and Barrie Dale in the 1960s on modern dinoflagellate encystment and excystment. A summary of the pioneering work of David Wall and Barrie Dale was given in Palynology, 28: 1-13 (2004). Furthermore, the capability to understand the morphology and relationships of dinoflagellate cysts, and how to apply them stratigraphically, was achieved only after the monumental work by William R. Evitt and his co-workers, throughout the 1960s and beyond (see for example Evitt, 1961; 1963; 1967; 1985; Downie et al., 1963; and Evitt and Davidson, 1964). A groundbreaking forum on dinoflagellates was held on the first day of the $6^{\text {th }}$ AASP Annual Meeting at Anaheim, California in October 1973. It comprised presentations by experts, including William R. Evitt and David Wall, and panel discussions on the stratigraphic application of dinoflagellate cysts; the proceedings were published (Evitt [ed.], 1975). The use of dinoflagellate cysts was, therefore, a second stage in the evolution of industrial palynology. It is not merely coincidence that Barrie Dale, William R. Evitt, and David Wall are all recipients of the AASP Medal for Scientific Excellence (Appendix 1).

This trend was accelerated by major advances in laboratory preparation techniques, and both light and scanning electron microscope technology. During this era, $\mathrm{PhD}$ graduates in palynology were recruited by $\mathrm{m}$ presidentajor oil companies, largely in the U.S.A. However, in the late 1950s, when industry began to turn to palynology for some of the solutions to its exploration/development problems, there were hardly any universities training palynologists. Industry initially solved this problem by offering interested geologists within their ranks the opportunity to be trained as palynologists. As the demand for trained palynologists for industrial and geological survey positions grew, the universities began to respond with graduate programs in palynology. This gradually increased the supply of palynologists to meet the rapidly increasing demand. During the 1960s and 1970s, there were approximately 30 universities throughout North America offering graduate training in various aspects of palynology.

In response to the heightened profile of industrial palynology, 32 palynologists founded the American Association of Stratigraphic Palynologists (AASP) in 1967 (Traverse and Sullivan, 1983, pl. 1). These 32 founding members of AASP are listed as Appendix 2. The inaugural meeting took place on the $8^{\text {th }}$ of December 1967 , at the Research Center of the Pan American Petroleum Company (which later became Amoco, and now is BP), Tulsa, Oklahoma. The aims of the fledgling AASP were to promote the science of palynology, especially as it relates to stratigraphic applications and biostratigraphy, to foster the spirit of scientific research among its members, and to disseminate information relating to palynology (Anonymous, 1968). Annual dues were US\$5.00 and Paul W. Nygreen of Chevron was the first President. Of the other six elected officials, four (George R. Fournier, Lewis E. Stover, Robert L. Tabbert, and Charles F. Upshaw) were from major oil companies. The remaining two Board 
members were drawn from the public sector. D. Colin McGregor worked for the Canadian Geological Survey and Alfred Traverse, the first Secretary-Treasurer, was a professor at Pennsylvania State University (Appendix 3).

The purpose of this contribution is to review the achievements, development, and history of AASP, since its foundation in 1967. This is a companion paper to Traverse and Sullivan (1983), who described the formation and early history of AASP. A listing of all those who have served on the Board of Directors of AASP is presented as Appendix 3.

\section{THE HISTORY OF AASP}

Traverse and Sullivan (1983) outlined the prehistory of AASP, the formation of the Association, and described the early years (1967-1970). A digital version of Traverse and Sullivan (1983) can be freely downloaded from the AASP Website at http://www.palynology.org/history/traverse83.html. This contribution briefly reviews the prehistory and early years, then goes on to discuss the development of AASP during the 1970 s to the present day.

\section{Prehistory}

The prehistory of AASP was described by Traverse and Sullivan (1983) and Traverse (2008). These authors observed that the early years of the modern era of palynology, i.e. between 1916 and the early 1950s, were dominated by the study of Holocene pollen. The first North American publication dedicated to palynology was the Pollen and Spore Circular, which was an irregularly published newsletter issued between 1943 and 1954 (Traverse, 2007, p. 23-24). Another focus for palynology in North America at this time was the Paleobotanical Section of the Botanical Society of America (PSBSA) (Traverse, 1960). Five 'National Pollen Conferences' were held in the U.S.A. between 1953 and 1958; the last two of these were under the aegis of the PSBSA. Members of the PSBSA fell into two camps. These were macropaleobotanists with largely botanical backgrounds, and palynologists who were generally geologists. In the late 1950s, many of these palynologists were biostratigraphers working for oil companies and this dichotomy caused some difficulties in the PSBSA (Traverse, 1974). There were discussions at the Fifth National Pollen Conference in 1957, led by John F. Grayson, regarding a separate palynology society. Traverse and Sullivan (1983) commented that the initiative by Grayson might well have led to the formation of AASP ten years before it actually happened.

The inception of a series of regular international palynological conferences, normally every four years, gave some focus to stratigraphic palynology in the U.S.A. The first of these was held in Tucson, Arizona in 1962, and the second in Utrecht, The Netherlands in 1966. These two meetings both bore the title International Conference on Palynology (ICP), and were independently organized. Following the Utrecht meeting, they were organized by the International Commission for Palynology (also ICP), a body formed from the paleontological section of the International Union of Geological Sciences (IUGS). The International Commission for Palynology sponsored the third international conference held at Novosibirsk, U.S.S.R., in 1971. Because of the concordance of the acronym ICP, the title of the Novosibirsk meeting was the Third International Palynological Conference (IPC). At the sixth meeting in Calgary, Canada in 1984, the International Commission for Palynology became the 
International Federation of Palynological Societies (IFPS) (see

http://geo.arizona.edu/palynology/ifps.html). The name of the meetings was also changed from the International Palynological Conference to the International Palynological Congress (IPC). The first International Palynological Congress organised by the IFPS was held in Brisbane, Australia in 1988. Traverse and Sullivan (1983, p. 10) stated that the formation of the International Commission for Palynology was, albeit indirectly, the stimulus for the formation of AASP.

\section{The formation of AASP}

Traverse and Sullivan (1983) described how the first discussions pertaining to a North American palynology society took place in Krefeld, Germany, during August 1966. The principal topic at this meeting was to discuss an Indian proposal to have a global palynological organization whose headquarters would be Lucknow. Following discussions regarding the formation of a North American palynology group, Herbert J. Sullivan of Amoco agreed to disseminate a questionnaire to gauge support for this concept. He sent out the so-called 'Sullivan Circular' (Traverse and Sullivan, 1983) to 262 palynologists in early 1967, and an overwhelming majority of these voted in favor. This led to the organization of the $8^{\text {th }}$ December 1967 meeting mentioned earlier. The concept of a society was agreed on, and the name 'American Association of Stratigraphic Palynologists' was selected, narrowly defeating 'Society of North American Palynologists (SNAP)'. The duties and election of officers was then decided upon, prior to the election of the first Executive Committee, who met the next day.

\section{The early years, 1967-1970}

Following the founding meeting, AASP membership stood at less than 40 . This grew rapidly to over 200 by the end of 1968 and then stayed stable at, or close to, this level for some time. Traverse and Sullivan (1983) noted that several prominent North American palynologists did not join AASP at this time for various reasons. Among these were fears that AASP would be oil company-dominated, and/or that the Association should be affiliated to a larger organization such as IFPS. The first three annual meetings were successful and these all stimulated membership levels. Traverse and Sullivan (1983) reported that the Executive Committee at this time was a small and dedicated group whose cohesiveness helped to effectively nurture this young organization.

\section{The 1970s and 1980s}

Through the 1970s, membership numbers of the Association increased, as did its financial assets (Text-Figures 1, 2). The Association was healthy, and the menmbership was now truly international. With the oil boom in the 1980s, membership numbers increased significantly as the petroleum companies created large biostratigraphy groups to service their vast exploration portfolios. Companies such as the Amoco Corporation employed over 80 biostratigraphers during this time, many of those being palynologists who were extremely active in AASP activities (J. M. Armentrout, unpublished information 1998; Text-Figure 3). Numbers published in the AASP Newsletter indicated that the membership was over 1000. However this number is somewhat inflated because delinquent members were not removed from the 
membership files for periods up to five years (Gordon D. Wood, personal communication (Text-Figure 1). Today the common practice as outlined in the bylaws is to purge the membership file of any member more than six months in arrears with membership dues.

\section{The 1990s to the present}

During the 1990s, the Association continued to be a vibrant, international scientific body. However the downturn in oil prices, and the subsequent reduction in the workforce of biostratigraphers, would have a profound impact over the next decade and into the new century (Farley and Armentrout, 2000). Despite fewer numbers of palynologists in the petroleum industry, the finances of the Association continued to improve. This was primarily due to the assistance provided by certain oil companies in mailing the quarterly AASP Newsletter and the journal, Palynology. The Amoco Corporation and the Mobil Corporation were major contributors to this effort, and in large part the recent financial stability of the Association can be attributed to this help. As the petroleum industry continued to decline through the 1990s, many biostratigraphers were forced into early retirement. Membership in AASP mirrored this trend, and likewise declined. This is a trend that, unfortunately, continues today (Text-Figure 1). In recent years without the support of members working in the academic and public sectors, and those specializing in Quaternary palynology, AASP membership numbers would be at even more critical levels.

The significant increase in non-biostratigraphic palynology over the past decade has shifted the focus of the Association, from being largely petroleum-based, to one which embraces all aspects of palynology. This expansion includes Quaternary and modern pollen research, as well as aeropalynology, melissopalynology, and anthropological, archaeological, forensic, and medical palynology. Although nonpaleopalynology was championed by many of the early AASP members such as Vaughn M. Bryant Jr. and Owen Davis, it is only recently that it has moved to the forefront of the Association. One of the most novel and unique applications of palynology is in forensic geoscience, which is practiced mainly in New Zealand, but also now in the United Kingdom and the United States (Bryant et al., 1990; 1996; Bryant and Mildenhall, 1998; Bryant and Jones, 2006; Riding et al., 2007). Forensic palynology is a technique which is growing rapidly in importance in criminal investigations (Milne et al, 2005).

The international nature of AASP is of interest. Not only did the word 'stratigraphic' have major relevance early in the history of the Association, the term 'American' also had a significant role. Throughout the early years of the Association, the membership was largely North American with few international members (Traverse and Sullivan, 1983). With easier communication via the advance of information technology since the mid/late 1980s, AASP has become a truly international organization. Well over half of the current membership is now from outside North America (Text-Figure 4). This proportion has increased over the past decade, with the majority of non-US members living in Europe. Now the AASP Newsletter is disseminated via e-mail attachment, and with ever-increasing internet access, it is hoped that modern technology will introduce the Association to more palynologists.

Traverse and Sullivan (1983) discussed opposition during the early years of AASP to the organization being independent, rather than affiliating to a larger scientific body. While independent meetings enhanced interactions between 
palynologists, this had the adverse affect of potentially lowering the profile of palynology within the broader geoscientific realm. This largely comprised the awareness among geologists of the capability of palynology to resolve various geological problems. Likewise, stand-alone AASP meetings may have diminished awareness within the organization of 'cutting edge' problems in geology where palynology might usefully be applied. For example, this relative isolation may explain the relatively late participation by palynologists to integrated multidisciplinary studies such as the Deep Sea Drilling Project (now renamed as the Ocean Drilling Program). To rectify these growing concerns, two significant events during the 1990s provided AASP with new avenues of exposure. The first occurred in 1992 when AASP became an Affiliated Society of the American Geological Institute (AGI). With this affiliation came the opportunity to provide annual articles to the discipline issue of Geotimes. This highlights all the geological disciplines with short articles. Since the affiliation with AGI, the important papers, research, and scientific meetings on palynology during the previous year are reviewed in Geotimes. Another significant event for AASP occurred in 1997, when the Association became an Associated Society of the Geological Society of America (GSA). The purpose of this affiliation was to introduce the general geological community to palynology through our participation in the large GSA Annual Meeting. In 2000, AASP held its first annual meeting in conjunction with GSA in Reno, Nevada. A second annual meeting with GSA was held in Philadelphia, Pennsylvania, in 2006. At both these meetings, AASP members sponsored technical sessions on selected aspects of research in palynology to the general geological community. Additionally, a space in the general Exhibits Hall allowed AASP to display and disseminate its publications, and attract new members.

AASP has also sponsored, or co-sponsored, several of the regular International Palynological Congresses. These meetings are normally held every four years, and are open to all palynologists; they were described in detail in the prehistory section above. Importantly, AASP was the primary sponsor of the $9^{\text {th }}$ International Palynological Congress held in Houston, Texas, in 1996. It has co-sponsored three other of these meetings (Appendix 4), with AASP members playing a prominent role in their respective successes.

In early 2007, AASP became an Associated Society of the American Association of Petroleum Geologists (AAPG), and is working towards affiliation with the Society for Sedimentary Geology (SEPM). Such efforts will ensure that AASP members and publications are integral to these larger associations.

\section{THE AASP FOUNDATION}

The AASP Foundation was inaugurated in 1976, when it was separated from AASP Incorporated. This was to create a vehicle for the receipt of tax-deductible donations to support AASP publications. All AASP publications excluding the quarterly AASP Newsletter were, from 1976 onwards, published by the AASP Foundation. The Foundation received tax exempt status on $17^{\text {th }}$ May 1976 , and is currently a 501(c)(3) not-for-profit, public organization. This means that any contributions are fully tax-deductible from U.S. Federal income tax returns. Furthermore, many employers have a matching gift program where personal gifts to not-for-profit organizations are matched.

The trust agreement for the AASP Foundation requires an arm's length relationship between it and AASP Incorporated. The two agencies are, in legal terms, completely separate entities. Hence a motion was passed at the mid-year Executive 
Committee meeting on $15^{\text {th }}$ April 1977 to exclude elected AASP Incorporated officers from serving as a trustee of the AASP Foundation. This restriction is, of course, only applicable during that person's term of office for AASP Incorporated. At that time it meant that Raymond A. Malloy had to leave the Board of Trustees of the AASP Foundation because he also served as an officer of AASP Incorporated. The first Chair of the AASP Foundation was Norman Norton; the first trustees were Robert T. Clarke and Raymond A. Malloy, later replaced by Richard W. Hedlund to avoid conflict with the Federal law.

\section{THE AASP BOARD OF DIRECTORS}

The Board of Directors of AASP Incorporated currently comprises 10 persons. The Executive Officers are President, Past-President, President-Elect, Managing Editor, Secretary-Treasurer, and Webmaster; there are also four Directors-at-Large. Although the Directors-at-Large have no specific portfolio, these persons frequently help with running Board elections and similar tasks. The Director-at-Large positions are an opportunity for members wishing to provide input to the Board to do so. Furthermore, the Directors-at-Large can observe the duties of the executive officers, with a view to possibly presenting themselves for election to the executive in the future. The term of office for Directors-at-Large is two years, with two of the four being elected each year. The Directors-at-Large replaced Councillors in 1979. The AASP Councillors, who served between 1967 and 1979 (see Appendix 3), included Past-Presidents and acted as respected advisors to the Board. The Councillors were chosen on the basis of their experience and insight. Note that the Editor of the AASP Newsletter does not serve as a Board member. A listing of the persons who have served on the AASP Incorporated Board is given as Appendix 3, and 11 PastPresidents are pictured in Plate 1.

When a person is elected President, he or she serves for a total of three years, as President-Elect, President, and Past-President, each for one year. This scenario allows a degree of continuity of leadership, supplementing the overlapping terms of the Directors-at-Large. Note that the Past-President has only served as a Board member between 1967 and 1979 and since 1992. Barbara L. Whitney was the first Executive Past-President in 1992. However, between 1967 and 1979, following their one year as President, he or she became a Councillor during the succeeding year (Appendix 3). The other three officers, i.e. Managing Editor, Secretary-Treasurer, and Webmaster, are elected annually.

Each member of the Board is expected to attend three meetings per year. A midyear meeting is held one Saturday each March or April. This normally lasts all day and has often been held at the venue of the annual meeting that year so that the Board members can view the site, and perhaps help with logistics. Any awards to be presented at that year's annual meeting are discussed at the midyear meeting. During each annual meeting, the Board of Directors meet twice; these gatherings are termed the 'outgoing' and 'incoming' Board meetings. The most important gathering is the first one, the outgoing Board meeting. This is a normal Board meeting and all Association business is discussed. The incoming Board meeting typically is relatively short, and is held after the business luncheon. This is an opportunity for the incoming President to chair his or her first Board. Most business will have been transacted at the outgoing Board meeting, but the date and venue of the following midyear meeting is finalized at this time, and a report is presented pertaining to the ongoing annual meeting. 


\section{AASP PUBLICATIONS}

One of the three stated main aims of the Association is to disseminate information relating to palynology, and the many and varied publications are among the finest achievements of AASP. The society has seven types of publication; these are an annual Journal (Palynology), an irregularly appearing Contributions Series, a Newsletter, textbooks, field trip guides, a membership directory, and miscellaneous publications. These different formats allow AASP to publish a wide variety of styles of publication. All AASP publications are produced under very high editorial and presentational standards; Palynology and the Contributions Series are peer-reviewed.

Palynology (ISSN 0191-6122) is the annually-published serial journal and is distributed to all members; volume one was issued in 1977. Typically, each volume includes around ten articles, in addition to all the abstracts, award citations, and the group photograph from the annual meeting held during the previous year. The original research articles may or may not have been given as oral presentations at an AASP meeting, however the other elements, such as the abstracts, represent the proceedings of the previous annual meeting. The editorial policy is to attempt to publish highquality articles and achieve a balance of subject matter, with global coverage and significance. In the early years of AASP, the Association used Geoscience and Man, as the serial journal. This was published by the School of Geoscience, Louisiana State University, and Traverse and Sullivan (1983) described how the non-consecutive volume numbering scheme of the AASP editions of Geoscience and Man caused significant confusion to some libraries. The proceedings of the 1968 to 1974 annual meetings were published in seven volumes numbered between I to XV of Geoscience and Man. In 1977, Palynology was established and it is now a premier journal in the discipline. Since 2005, Palynology has been included in the Science Citation Index. The journal is also listed in other databases including Elsevier and the Web of Science administered by Thomson Scientific. Palynology is also available online through BioOne, GeoScienceWorld (GSW), and JSTOR. Note that JSTOR is not an acronym; it is an organization that maintains an archive of important scholarly journals, and provides access to them (see http://www.jstor.org). A light-hearted account of the production and distribution process for Palynology was given by Jarzen (2007).

Some manuscripts submitted to the AASP Managing Editor are too large for inclusion in Palynology. Suitable larger manuscripts are published in the American Association of Stratigraphic Palynologists Contributions Series (ISSN 0160-8843). This is an irregularly-appearing series, and is distributed to institutional members and is sold to the individual membership and the general public. The first number was issued in 1970, and number 43 was published in 2006. This series includes botanical keys, pollen atlases, catalogs, glossaries of terminology, indexes of taxa, monographs, symposium proceedings, and sets of papers on particular topics.

Some extended contributions merit publication as stand-alone textbooks and the AASP Foundation published the first of these in 1985. This was Sporopollenin Dinoflagellate Cysts - their Morphology and Interpretation by William R. Evitt and is a hardback volume of 333 pages. Evitt published this landmark text prior to his retirement from Stanford University in 1986. He was the world leader in the study of fossil dinoflagellates and Evitt (1985) was based on the manual of a short (two-week) course on dinoflagellate cyst morphology that he had been presenting since 1971 . Subsequently, the AASP Foundation has published six other textbooks, four of which are themed sets of articles. In 1996, AASP published by far its most ambitious 
contribution to date. This was a lavishly-produced, three-volume boxed set entitled Palynology: Principles and Applications, expertly edited by Jan Jansonius and D. Colin McGregor. It is a comprehensive, state-of-the-art, text on palynology and includes 32 chapters written by more than 100 experts in their respective specialist areas. This project was eminently successful because within several years, Jansonius and McGregor (1996) sold out; reprints were published in 2002 and 2007.

The AASP Foundation has published eight miscellaneous publications and two pollen photomicrograph posters since 1975. These publications include manuals for short courses, a scanning electron microscope atlas of living dinoflagellates, and workshop notes. This is not a formal series, and this flexibility allows several different formats to be used. Field excursions are regularly organized as part of AASP annual meetings, and the organizers of these field trips produce guides which are distributed to all participants. In certain cases these guides are distributed after the excursion. Some of these have sold out; currently 19 AASP field trip guides from 1971 to 2005 are available.

Four numbers of the AASP Newsletter (ISSN 0732 6041) are produced each year, and this publication is the principal communication to the membership. The AASP Newsletter includes a column written by the President, information on annual meetings, ballot details, correspondence from regions outside North America, and book reviews. In recent years it was decided to distribute the AASP Newsletter to the individual membership electronically. The listing of members of the AASP Board of Directors (Appendix 3) was principally compiled from back issues of this publication. The AASP Newsletter archive is therefore the main documentation of the activities of the Association, and of the wider developments in the science of palynology, since 1968. All the AASP Newsletters from 1968 to 2002 are now available in pdf format on a compact disc. The AASP Membership Directory (ISSN 0192 7280) lists the addresses and contact details of all individual and institutional members; it is currently produced every two years.

\section{THE AASP WEBSITE}

The Association has demonstrably embraced technological change. The AASP website was created in 1995 by Martin J. Head and it was hosted at the University of Toronto, Canada. This debut of AASP on the information superhighway showcased various aspects of the Association such as advertising meetings of interest and listing the Board of Directors. Martin J. Head remained AASP webmaster until 2000, when the website moved to Boston College, Weston, Massachusetts, under Paul K. Strother. In an important initiative during March 2002, the website was upgraded so that credit card payments could be securely made electronically for membership dues and publications. Also in 2002, the website again changed location to the University of Arizona under the current webmaster Owen K. Davis. In recent years, the website (currently http://www.palynology.org) has expanded to become a treasure of palynological information providing important information to AASP members, the palynological community, and any other interested parties. It also acts as the repository for AASP historical documents, and interviews with past and present AASP members who have made significant contributions to the Association. In 2006, the AASP by-laws were emended to include the Webmaster as a member of the Board of Directors.

\section{AASP MEETINGS}


Through the hard work of volunteers, AASP has held an annual meeting every year since the inaugural gathering in Tulsa in 1967. The annual meeting is typically held in a large American city during the Fall months, and lasts for three to five days. The venues of all these 41 meetings are listed in Appendix 4. The first annual meeting was held in Baton Rouge, Louisiana between the $17^{\text {th }}$ and $19^{\text {th }}$ October 1968 . The annual meetings now reflect the international membership, and the first annual meeting to be held outside North America was in 1982, when the venue was Dublin, Ireland. Since 1998, the Association has met outside the U.S.A. and Canada in five of these ten years. The Board of Directors normally hold their outgoing board meeting on the first day, normally a Sunday. The next three days are then given to scientific proceedings, which are usually themed oral presentations and poster sessions. There are normally field trips associated with these conferences, and frequently specific workshops are presented. A varied social program is included, and the AASP business luncheon is held during the final day. This is an informal luncheon during which reports by the Managing Editor, Secretary-Treasurer, and Webmaster are presented. A report on the AASP Foundation is also given, and the President of the day, hands over to the new President; both these persons normally deliver short speeches. Any AASP awards are presented during the business luncheon.

Four of the annual meetings have been held in conjunction with the International Palynological Congress, i.e. Aix-en-Provence, France (1992), Houston (1996), Granada, Spain (2004), and Bonn, Germany (2008). Two annual meetings, Reno in 2000 and Philadelphia in 2006, were held at the annual meeting of the Geological Society of America (GSA) as a result of the affiliation with GSA. A further four meetings were held jointly with other micropaleontological organizations. The first two of these were Halifax, Nova Scotia, Canada in 1976 and Dublin, Ireland in 1982, which were both held jointly with the Commission Internationale de Microflore du Paléozoique (CIMP). The next joint meeting was in London, England in 2002, when the partners were The Micropalaeontological Society (TMS) and the North American Micropaleontology Section (NAMS) of SEPM. One year later in 2003, a joint meeting with the Canadian Association of Palynologists (CAP) and NAMS/SEPM was held at St. Catharines, Ontario, Canada. Most of the annual meetings however have been sponsored by local committees and, with the exception of those listed above, have been events primarily intended for the membership. A few cities have hosted more than one AASP annual meeting; these are Baton Rouge (1968; 1993), Halifax (1976; 1987), Houston (1975; 1988; 1996), and Tulsa (1977; 1989). All other locations have hosted only one AASP annual meeting. Unsurprisingly, Texas has hosted seven AASP annual meetings within its borders (Appendix 4).

The future program of AASP meetings is a varied and exciting one. In 2009 the conference will be held at Kingsport, Tennessee. We will revisit Halifax in 2010, before returning to Europe in 2011 at Southampton, U.K.

\section{AASP AWARDS}

As recognition of significant scientific achievement, and/or the devotion of time to the Association as appropriate, five AASP awards are presented to recognize these efforts. These, and all the recipients, are listed in Appendix 1. The prestigious AASP Medal for Scientific Excellence is awarded to scientists who have made fundamental contributions to the development of palynology. The first AASP Medal 
for Scientific Excellence was awarded to William R. Evitt in 1982. Nine other medals have been awarded since, largely to dinoflagellate workers. The AASP Medal for Excellence in Education was initiated in 1999 to recognize persons who have been leaders in palynological education/instruction, who have consistently demonstrated excellence in palynological instruction, and who have trained practicing palynologists. Only three of these Medals have been awarded; to Aureal T. Cross in 1999, Alfred Traverse in 2001, and William R. Evitt in 2006. To reward those persons who have made, or are making, fundamental contributions to palynology and generous contributions to AASP, Honorary Life Membership can be awarded. This award includes lifetime membership to the Association. When Honorary Life Membership was instigated, it was felt that if such awards were presented to prominent nonmembers of AASP, this would help promote membership of the Association. The inaugural Honorary Life Member was Alfred Eisenack in 1975. Eleven other Honorary life Members have been conferred, the latest two being Alfred Traverse and Vaughn Bryant, Jr. in 2005. A lifetime achievement award for extensive and longstanding contribution to both AASP Inc. and the AASP Foundation was presented in 1994 to Robert T. Clarke for his prodigious, and ongoing, commitment to the Association. The Distinguished Service Award is given to those members who have consistently given their time and resources to advance AASP. The first Distinguished Service Awards were given to Robert T. Clarke and Norman J. Norton in 1978, and the last ones to Owen K. Davis, David K. Goodman, and David T. Pocknall in 2005. In all, 15 of these awards have been presented.

At Annual Meetings, through a donation from L.R. Wilson, an award is given to the best student oral presentation. The student receives a $\$ 1,500$ stipend, and two years free membership of the Association. Students may also apply annually for the AASP Student Scholarship, two of which are presented to students who are conducting significant scholarly palynological research. A third scholarship, the Cranwell Smith Award, is given to a deserving student from the University of Arizona. This award was endowed by Lucy Cranwell and Watson Smith on November 4, 1983 via a gift of over \$10,000 to the University of Arizona. The principal endowment has been increased over three-fold through donations from industry and the friends of Lucy Cranwell. The purpose of the Cranwell Smith Award is to support palynological research by graduate students at the University of Arizona. Recently at annual meetings, an award has been given to recognize the best overall poster presentation and, more recently, the Board of Directors decided to present an award to the best student poster presentation.

\section{THE AASP CENTER FOR EXCELLENCE IN PALYNOLOGY (CENEX)}

A long term strategy has been developed by AASP to provide a consistent supply of highly trained palynologists for the foreseeable future. Piel (2007) noted that, from the early years of AASP, several leaders of the association were acutely aware of the need to obtain one or more Endowed Chairs to ensure that university places would always be available to train graduate students in palynology. This initiative was discussed almost from the inception of AASP, but without a process or a vehicle to realize this ambitious goal until 1989.

The early planning of this ambitious project was initiated in 1988 by the then AASP President Harry Leffingwell, and it was carried forward by Kenneth M. Piel. Both Leffingwell and Piel worked for the Unocal Corporation at this time. The aim was to create an AASP Center for Excellence in Palynology (CENEX) at a university 
in the U.S.A., then gather donations which would be used to establish two Endowed Chairs in Palynology. CENEX would accept graduate students interested in palynology from around the world to be trained in accordance with the goals set forth in an Endowment Agreement.

The AASP Board of Directors at the time approved the plan for CENEX. Following agreement by the Board, questionnaires were sent to several universities, and site visits of up to two days were made to each university by Kenneth M. Piel and, in some cases, Stephen Hall (University of Texas, Austin). Responses to the questionnaires were received, and an extensive report was prepared for the AASP Board with rankings of these sites. Finally, representatives of each university were invited to attend the AASP midyear Board meeting in 1990 to clarify any points not already clear to the Board. Seven universities were chosen as potential candidates. The seven institutions were Louisiana State University, Michigan State University, The Pennsylvania State University, Texas A\&M University, The University of Arizona, The University of Oklahoma, and The University of Texas at Austin. The selection of these seven universities was based on them all being institutions which either had been leaders in the teaching of palynology during the recent past, and/or at where there was a good track record in fund raising (Piel, 2007). The Department of Geology and Geophysics at Louisiana State University (LSU) was ultimately chosen to host CENEX. This decision was taken at the midyear Board meeting in 1990 held at Denver, Colorado and the major fund raising effort was began almost immediately after this important meeting (Piel, 2007). The LSU Foundation approved an Agreement prepared by AASP during 1990/1991, and the Agreement was signed by both parties in 1992. Shortly thereafter, the late John H. Wrenn was chosen by the University to be the first Director of CENEX.

The principal goals of CENEX are reproduced below. They are taken from the current Endowment Agreement, which is identical to the initial Agreement, except for the reduction from two Chairs to one:

"This Fund will be used to establish the American Association of Stratigraphic Palynologists (AASP) Center for Excellence in Palynology (CENEX) and will establish an endowed AASP Chair in Paleopalynology in the Department of Geology and Geophysics. The Holder of the Endowed Chair shall be the Director of CENEX."

Furthermore, the primary objectives of the Chair, and of CENEX, are:

“(1) To promote excellence in the teaching of applications-oriented stratigraphic paleopalynology, with particular reference to the contributions paleopalynology can make toward chronostratigraphy and paleoecology, and toward resolving geological problems in the collateral disciplines of stratigraphy, sedimentology, sequence stratigraphy, geochemistry, paleoecology and kerogen studies; and to train, advise, and direct graduate students to graduate degrees so that those individuals become broadly capable geologists with special expertise in biostratigraphy and paleoecology.

(2) To promote scholarly research and publication in paleopalynology.”

During the early 1990s, the challenging task was started to collect two endowments of US\$600,000 each. These would then be both matched by the State of Louisiana, bringing the total amounts for each Endowed Chair to US\$1,000,000. 
Early donations of US\$100,000 each were received from the Amoco Corporation, the Exxon Corporation, and the Unocal Corporation. Other oil companies, such as Chevron, ConocoPhillips, and Texaco, also made substantial donations. Many individuals made generous donations which accumulated over subsequent years; these include approximately 30 AASP members, who donated up to US $\$ 1,000$ or more each. CENEX also benefited from the donation of equipment (e.g. centrifuge units and microscopes), literature collections, modern pollen collections, and sample material from both companies and individuals. However, the downturn in the oil industry throughout the remainder of the 1990s significantly reduced other potential sources of funding (Farley and Armentrout, 2000). The single exception was the approximately US\$121,000 given to CENEX from the estate of Paul Wesendunk, a retired Chevron palynologist. In recognition of this, the laboratory at CENEX was named in honor of Paul Wesendunk. Despite the addition of this large sum, it became evident that funding two Endowed Chairs would be extremely difficult. Hence in 2002 the original Agreement was amended, and a sum from the Endowment Fund was withdrawn. These monies were taken in order to erect an AASP Professorship to replace one of the original Endowed Chairs. Matching funds for this were obtained from the State of Louisiana, and the Endowed Professorship was held by John H. Wrenn until mid-2006 when he retired due to health issues. Unfortunately John passed away in late 2006, but his hard work and legacy have left a strong foundation for the future of CENEX at LSU.

Recently, an amended Agreement was signed between AASP, the LSU Foundation, and the LSU School of Basic Sciences. The agreement ensures that two academic paleopalynology positions for CENEX will be kept in place by LSU. Funding for the AASP Endowed Chair in Palynology has now reached the US\$600,000 goal, and the LSU College of Basic Sciences has submitted the application to the Louisiana State Board of Regents for matching funds. AASP should have learned if this application has been successful by mid-2008. Soon after receipt of the matching funds, a search will begin to fill the Endowed Chair. At the time of writing, Dr Sophie Warny has accepted a tenure-track faculty position that includes a joint appointment in the Department of Geology and Geophysics and the Museum of Natural Sciences, and to the AASP Professorship, which will allow her to use earnings from the Professorship to support her research activities as they relate to CENEX.

\section{THE NAME OF THE ASSOCIATION}

As previously noted, in a ballot of the founding members, the name 'American Association of Stratigraphic Palynologists' only narrowly beat 'Society of North American Palynologists'. The name of the Association has been informally debated over the years, and recently the Board have discussed it at some length. It is clear that, when AASP was founded, palynostratigraphy related to the North American oil industry was the core business of the majority of the membership. This aspect is still important, but it is abundantly clear that AASP is now a truly international learned society (Text-Figure 4). Furthermore, the applications of palynology among the membership, and the wider community, are extremely diverse and certainly not confined to biostratigraphy. It is the aspiration of the Board of Directors that the name of the society should properly reflect its membership and their endeavours, and moreover should be worded so as to appeal to new palynologists all over the world. So the discussions pertaining to the name have intensified in recent years. Indeed, in 
the opening address at the 2007 Annual Meeting in Panama City, Alfred Traverse proposed changing the name of the Association to 'The Palynological Society' (Traverse, 2008). As a result of these deliberations, the Board of Directors decided unanimously at the outgoing Board meeting held in Panama City on September $9^{\text {th }}$ 2007 that the membership should be consulted on its willingness to change the name of the Association. The rationale for this proposal was summarized by McCarthy (2007). A ballot paper was distributed to all individual members in good standing on $20^{\text {th }}$ March 2008. The question on the ballot sheet was: 'Do you agree that the society's name be changed from 'American Association of Stratigraphic Palynologists, Inc. (AASP)' to 'AASP - The Palynological Society'? It was felt that retaining the acronym AASP provides continuity with the past, and would help the legal process of the name change. This concept followed the precedent set by the former Society of Economic Paleontologists and Mineralogists, when it changed its name to 'SEPM Society for Sedimentary Geology'. The result of this ballot was that the membership overwhelmingly endorsed this proposed name change. Hence the Board will now formally change the name of the Association to 'AASP - The Palynological Society'.

\section{SUMMARY}

There is no doubt that AASP has evolved significantly into an international Association since its beginnings in 1967. It was initially thought that the terms 'American' and 'Stratigraphic' could potentially alienate some palynologists. Rather than this, AASP has grown and thrived despite industry downturns and the reduction in the biostratigraphic workforce since the mid 1980s. By reaching out, via modern information technology, to the full and varied spectrum of palynological research throughout the world, the Association will hopefully continue to expand under the new name of 'AASP - The Palynological Society'. This will only occur with the continued hard work of volunteers on the Board of Directors, so that the dedication of past Board members will be brought to fruition.

\section{ACKNOWLEDGEMENTS}

The authors wish to thank Harry A. Leffingwell, Kenneth M. Piel, Alfred Traverse, and the current Board of Directors for commenting on an initial draft of the manuscript. James B. Riding publishes with the approval of the Executive Director, British Geological Survey (NERC).

\section{References Cited}

ANONYMOUS

1968 American Association of Stratigraphic Palynologists: a new society. Journal of Paleontology, 42: 1093.

BRYANT, V.M, Jr. and JONES, G.D.

2006 Forensic palynology: Current status of a rarely used technique in the United States of America. Forensic Science International, 163: 183-197

BRYANT, V.M. Jr., and MILDENHALL, D.C.

1998 Forensic palynology: a new way to catch crooks. In: Bryant, V.M. Jr., 
and Wrenn, J.H. (eds.). New Developments in Palynomorph Sampling, Extraction and Analysis. American Association of Stratigraphic Palynologists Contributions Series, No. 33: 145-155.

BRYANT, V.M. Jr., JONES, J.G., and MILDENHALL, D.C.

1990 Forensic palynology in the United States of America. Palynology, 14: 193-208.

1996 Chapter 23C. Forensic studies in palynology. In: Jansonius, J., and McGregor, D.C. (eds). Palynology: Principles and Applications. American Association of Stratigraphic Palynologists Foundation, Dallas, 3: 957-959.

DOWNIE, C., EVITT, W.R., and SARJEANT, W.A.S.

1963 Dinoflagellates, hystrichospheres, and the classification of the acritarchs. Stanford University Publications, Geological Sciences, 7(3), 16 p.

EVITT, W.R.

1961 Observations on the morphology of fossil dinoflagellates.

Micropaleontology, 7(4): 385-420.

1963 A discussion and proposals concerning fossil dinoflagellates, hystrichospheres, and acritarchs, I and II. Proceedings of the National Academy of Sciences, 49(2-3): 158-164; 298-302.

1967 Dinoflagellate studies. II. The archeopyle. Stanford University Publications, Geological Sciences, 10(3), 83 p.

1985 Sporopollenin Dinoflagellate Cysts - their Morphology and Interpretation. American Association of Stratigraphic Palynologists Foundation, Dallas, 349 p.

EVITT, W.R. (editor)

1975 Proceedings of a Forum on Dinoflagellates held at Anaheim, California, October 16, 1973 as part of the Sixth Annual Meeting, A.A.S.P. American Association of Stratigraphic Palynologists Contributions Series, No. 4, 76 p.

EVITT, W.R., and DAVIDSON, S.E.

1964 Dinoflagellate studies. I. Dinoflagellate cysts and thecae. Stanford University Publications, Geological Sciences, 10(1), 12 p.

FARLEY, M.R., and ARMENTROUT, J.M.

2000 Fossils in the oil patch. Geotimes, 45(10): 14-17.

JANSONIUS, J., and McGREGOR, D.C. (editors)

1996 Palynology: Principles and Applications. American Association of Stratigraphic Palynologists Foundation, Dallas, 3 volumes, 1330 p. (reprinted 2002; 2007).

JARZEN, D.M.

2007 An order of Palynology to go, please! American Association of 
Stratigraphic Palynologists Newsletter, 40(1): 10-11.

MCCARTHY, F.

2007 A Rosa by any other name... might smell even sweeter? American

Association of Stratigraphic Palynologists Newsletter, 40(4): 5.

MILNE, L.A., BRYANT, V.M. Jr., and MILDENHALL, D.C. 2005 Chapter 14. Forensic palynology. In: Coyle, H.M. (ed.). Forensic

Botany. Principles and Applications to Criminal Casework. CRC Press LLC, Boca

Raton, Florida, U.S.A., p. 217-252.

PIEL, K.

2007 CENEX agreement signed in Houston, March 31 2007. American

Association of Stratigraphic Palynologists Newsletter, 40(2): 26-28.

POWELL, A.J., and RIDING, J.B. (editors)

2005 Recent Developments in Applied Biostratigraphy. The

Micropalaeontological Society, Special Publications. The Geological Society,

London, 245 p.

RIDING, J.B., RAWLINS, B.G., and COLEY, K. H.

2007 Changes in soil pollen assemblages on footwear worn at different sites.

Palynology, 31: 135-151.

STAPLIN, F.L.

1961 Reef-controlled distribution of Devonian microplankton in Alberta.

Palaeontology, 4(3): 392-424.

TRAVERSE, A.

1960 P.S.B.S.A. - the oldest organization of paleobotanists in the world.

Plant Science Bulletin (Botanical Society of America), 6(3): 1-4.

1974 Paleopalynology 1947-1972. Annals of the Missouri Botanical Garden, 61(1): 206-236.

2007 Paleopalynology. Second edition. Springer, Dordrecht, The

Netherlands, xviii +813 p.

2008 Founding the AASP: Critical mass reached in Tulsa in 1967.

Palynology, 32: xxx (abstract).

TRAVERSE, A., and SULLIVAN, H.J.

1983 The background, origin, and early history of the American Association of Stratigraphic Palynologists. Palynology, 7: 7-17

(http://www.palynology.org/history/traverse83.html). 
The Association recognizes outstanding achievements either to the science of palynology, or to the Association by the distribution of several awards and honors (see http://www.palynology.org/content/awards.html). This Appendix lists the recipients of the five categories of AASP honors, and the year of the award. Nominations for these awards should be made by AASP members to the Chair of the AASP Awards Committee, who is currently Martin B. Farley (mbfarley@sigmaxi.org). The procedures for AASP awards/honors are given in detail at http://www.palynology.org/content/awardproced.html.

\section{THE AASP MEDAL FOR SCIENTIFIC EXCELLENCE}

This is awarded to persons who have made fundamental contributions to the development of palynology. The ten recipients to date are dominated by dinoflagellate cyst workers from North America, Europe and Australia. This award is a plaque containing the AASP logo in the form of a medal, and is presented by the Chair of the AASP Awards Committee. Nomination packets are submitted to the Chair of the Awards Committee, who makes recommendations to the AASP President and Board of Directors. Details of the requirements for nomination packets can be found at http://www.palynology.org/content/awardproced.html\#mse. Nominations should be sent prior to March 1st, i.e. in time for consideration at the mid-year meeting of the Board of Directors, for potential presentation at the annual meeting.

$\begin{array}{lll}1 & \text { William R. Evitt } & 1982 \\ 2 & \text { William G. Chaloner } & 1984 \\ 3 & \text { Lewis E. Stover* } & 1988 \\ 4 & \text { Hans Gocht } & 1996 \\ 5 & \text { Graham L. Williams } & 1996 \\ 6 & \text { Svein B. Manum } & 2002 \\ 7 & \text { Barrie Dale } & 2004 \\ 8 & \text { David Wall } & 2004 \\ 9 & \text { Robin Helby } & 2005 \\ 10 \quad \text { Satish K. Srivastava } & 2006 \\ * \text { - deceased }\end{array}$

\section{THE AASP MEDAL FOR EXCELLENCE IN EDUCATION}

This medal is awarded to persons who have been leaders in palynological education/instruction, who have consistently demonstrated excellence in palynological instruction, and who have trained practicing palynologists. The three awardees to date are all retired, and all worked in the U.S.A. This award is a plaque containing the AASP logo in the form of a medal, and is presented by the Chair of the Awards Committee. Nominations are submitted to the Chair of the Awards Committee, who makes recommendations to the AASP President and Board of Directors. Details of the requirements for nomination packets can be found at http://www.palynology.org/content/awardproced.html\#mee. Nominations should be sent prior to March 1st, i.e. in time for consideration at the mid-year meeting of the Board of Directors, for potential presentation at the annual meeting. 
$\begin{array}{lll}\text { 1. } & \text { Aureal T. Cross } & 1999 \\ \text { 2. } & \text { Alfred Traverse } & 2001 \\ \text { 3. } & \text { William R. Evitt } & 2006\end{array}$

\section{AASP HONORARY LIFE MEMBERS}

This award is given to persons who have made, or are making, fundamental contributions to palynology and generous contributions to AASP. These may be persons who were not previously members of AASP. Honorary Life Members receive a certificate signed by the President and Board of Directors from the Chair of the Awards Committee and lifetime membership of AASP. Nominations are submitted to the Chair of the Awards Committee, who distributes nomination packets to the members of the Awards Committee for consideration. The Chair of the Awards Committee then makes recommendations to the AASP President and Board of Directors. Details of the requirements for nomination packets can be found at http://www.palynology.org/content/awardproced.html\#hlm. Nominations should be sent prior to March 1st, i.e. in time for consideration at the mid-year meeting of the Board of Directors, for potential presentation at the annual meeting.

* - deceased

$\begin{array}{lll}\text { 1. } & \text { Alfred Eisenack* } & 1975 \\ \text { 2. } & \text { William S. Hoffmeister* } & 1975 \\ \text { 3. } & \text { Leonard R. Wilson* } & 1975 \\ \text { 4. } & \text { Knut Faegri* } & 1977 \\ \text { 5. } & \text { Charles Downie* } & 1982 \\ \text { 6. } & \text { Lucy M. Cranwell* } & 1989 \\ \text { 7. } & \text { William R. Evitt } & 1989 \\ \text { 8. } & \text { Tamara F. Vozzhennikova* } & 1990 \\ \text { 9. } & \text { Aureal T. Cross } & 1991 \\ \text { 10. } & \text { Robert T. Clarke } & 2002 \\ \text { 11. } & \text { Vaughn M. Bryant Jr. } & 2005 \\ \text { 12. } & \text { Alfred Traverse } & 2005\end{array}$

\section{AASP BOARD OF DIRECTORS AWARD}

This award, a plaque or certificate awarded by the AASP President is given by the AASP Board of Directors to individuals who have made extensive and longstanding contributions to AASP. It is given infrequently to AASP members for a lifetime of service to AASP. The nomination and decision is made within the Board of Directors.

1 Robert T. Clarke

1994

\section{AASP DISTINGUISHED SERVICE AWARD}

This award is an engraved plaque, and is awarded by the Chairman of the Awards Committee to persons who have repeatedly and generously given their time and resources to AASP, and whose efforts have advanced the organization. 
Nominations for this award are submitted to the Chair of the Awards Committee, who makes recommendations to the President. Nominations are due on March 1, in time for consideration at the mid-yearly meeting of the Board of Directors, for presentation at the following annual meeting.

$\begin{array}{lll}1 & \text { Robert T. Clarke } & 1978 \\ 2 & \text { Norman J. Norton } & 1978 \\ 3 & \text { Jack D. Burgess } & 1982 \\ 4 & \text { Richard W. Hedlund } & 1982 \\ 5 & \text { John A. Clendening } & 1987 \\ 6 & \text { Kenneth M. Piel } & 1990 \\ 7 & \text { Gordon D. Wood } & 1993 \\ 8 & \text { Jan Jansonius } & 1995 \\ 9 & \text { D. Colin McGregor } & 1995 \\ 10 & \text { John H. Wrenn* } & 1998 \\ 11 & \text { Vaughn M. Bryant, Jr. } & 1999 \\ 12 & \text { Donald W. Engelhardt } & 2000 \\ 13 & \text { Owen K. Davis } & 2005 \\ 14 & \text { David K. Goodman } & 2005 \\ 15 & \text { David T. Pocknall } & 2005\end{array}$

* - deceased

APPENDIX 2 - Listing of the Founding Members of AASP

$1 \quad$ O. Ben Bourn

2 Robert T. Clarke

3 Fritz H. Cramer-Diez

4 William C. Elsik

5 George R. Fournier*

6 John F. Grayson

7 George F. Hart

8 Richard W. Hedlund

9 William S. Hopkins Jr.

10 Arthur E. LeBlanc

11 Dennis R. Logan

12 D. Colin McGregor

13 William C. Meyers

14 David R. Mishell

15 Paul W. Nygreen

16 Earl T. Peterson

17 Kenneth M. Piel

18 Delbert E. Potter

19 William A. S. Sarjeant*

20 Mart P. Schemel*

21 Bernard L. Shaffer

22 Howard M. Simpson

23 Lewis E. Stover*

24 Herbert J. Sullivan

25 Robert L. Tabbert 
26 Mel W. Thompson

27 Alfred Traverse

28 Charles F. Upshaw*

29 James B. Urban*

30 Logan L. Urban*

31 William F. von Almen

32 Graham L. Williams

* - deceased

APPENDIX 3 - A listing of persons who have served on the Board of Directors of AASP Incorporated, 1967 to 2007

\section{1a PRESIDENTS}

Paul W. Nygreen

Charles F. Upshaw

George R. Fournier*

Alfred Traverse

Geoffrey Norris

Donald W. Engelhardt

Robert T. Clarke

Richard W. Hedlund

Kenneth M. Piel

Richard L. Pierce*

William C. Elsik

Jack D. Burgess

James E. Canright

John E. Bennett

Lewis E. Stover*

Douglas J. Nichols

John A. Clendening

Vaughn M. Bryant Jr.

Raymond A. Christopher

Don G. Benson Jr.

Norman O. Frederiksen

Harry A. Leffingwell

Judith K. Lentin

Barbara L. Whitney

John H. Wrenn*

Robert L. Ravn

Lucy E. Edwards

E. Reed Wicander

Jan Jansonius

Gordon D. Wood

Rolf W. Mathewes

Christopher N. Denison

Fredrick J. Rich

David T. Pocknall

James B. Riding
1967-1968

1968-1969

1969-1970

1970-1971

1971-1972

1972-1973

1973-1974

1974-1975

1975-1976

1976-1977

1977-1978

1978-1979

1979-1980

1980-1981

1981-1982

1982-1983

1983-1984

1984-1985

1985-1986

1986-1987

1987-1988

1988-1989

1989-1990

1990-1991

1991-1992

1992-1993

1993-1994

1994-1995

1995-1996

1996-1997

1997-1998

1998-1999

1999-2000

2000-2002

2002-2003 
Sharma L. Gaponoff

Martin J. Head

Robert A. Cushman Jr.

Carlos A. Jaramillo

Francine M. G. McCarthy

Fredrick J. Rich

* - deceased

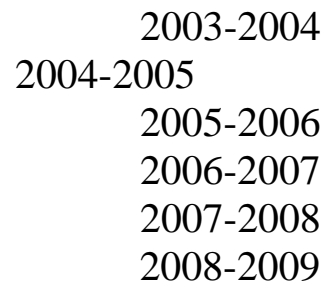

2003-2004

2004-2005

2005-2006

2006-2007

2007-2008

2008-2009

\section{1b VICE-PRESIDENTS}

Between 1967-1968, the elected Vice-President was a member of the Board of Directors, but did not automatically succeed the President in the following year.

Between 1967-1978 and 1978-1979 was when George R. Fournier was Vice President in 1968-1969 and President in 1969-1970. From 1979-1980, it was decided to move to a system where, when a new President is elected, he or she serves one year as President-Elect before becoming President the following year. Then, after the year of Presidency, he or she would serve the final year of the three-year term as PastPresident. In previous years, the Past President served as a Councillor. This system of a three-year Presidential term gives a high degree of continuity and stability.

Subsequently, Evan J. Kidson served as the last vice-President in 1978-1979.

D. Colin McGregor

George R. Fournier*

Geoffrey Norris

Donald W. Engelhardt

John W. Hall

Harry A. Leffingwell

Wayne W. Brideaux

William C. Elsik

M. Sedley Barss

John A. Clendening

Warren S. Drugg*

Evan J. Kidson

* - deceased
1967-1968

1968-1969

1969-1970

1970-1971

1971-1972

1972-1973

1973-1974

1974-1975

1975-1976

1976-1977

1977-1978

1978-1979

\section{MANAGING EDITORS}

Lewis E. Stover*

${ }^{1}$ Robert T. Clarke

1967-1970

1969

1970-1973

1973-1976

1976-1983

1983-1987

$1987-2000$

2000-2004

2004 to present

James B. Riding

* - deceased

${ }^{1}$ Robert T. Clarke was appointed Managing Editor in mid-1969 when Lewis E. Stover was transferred to Australia. 
Alfred Traverse

Robert T. Clarke

Herbert J. Sullivan

Jack D. Burgess

John A. Clendening

Kenneth M. Piel

Gordon D. Wood

David T. Pocknall

Thomas D. Demchuk
1967-1970

1970-1973

1973-1975

1975-1978

1978-1981

1981-1986

1986-1993

1993-1998

1998 to present

\section{WEBMASTERS}

Martin J. Head

1995 to 2000

Paul K. Strother

2000 to 2002

2002 to present

Note that the position of Webmaster was incorporated onto the Board of Directors in 2006.

\section{COUNCILLORS/DIRECTORS-AT-LARGE}

The non-Executive members of the Board of Directors have been known as Councillors and Directors-at-Large. Between 1967 and 1979, there were 3 councillors serving every year. The term of office of a Councillor was one year and one was always the Past President, except for the inaugural year of 1967-1968. By contrast, the term of office of a Director-at-Large is two years. There are a team of four, with two debutants/debutantes and two retirees each year.

\section{COUNCILLORS}

George R. Fournier*

1967-1968

Robert L. Tabbert

1967-1968

Charles F. Upshaw

1967-1968

Richard W. Hedlund

1968-1969

Paul W. Nygreen (Past-President)

$1968-1969$

Marcia R. Winslow

1968-1969

Daniel Habib

1969-1970

John W. Hall

1969-1970

Charles F. Upshaw (Past-President) 1969-1970

David Wall

1970-1971

Paul S. Martin

1970-1971

George R. Fournier* (Past President) 1970-1971

William R. Evitt

1971-1972

D. Colin McGregor

1971-1972

Alfred Traverse (Past President)

1971-1972

Wayne W. Brideaux

$1972-1973$

Warren S. Drugg*

1972-1973

Geoffrey Norris (Past President)

1972-1973

Donald W. Engelhardt (Past Pres.) 1973-1974

Glenn E. Rouse

1973-1974 


$\begin{array}{lr}\text { Graham L. Williams } & 1973-1974 \\ \text { Jack D. Burgess } & 1974-1975 \\ \text { Robert T. Clarke (Past President) } & 1974-1975 \\ \text { William W. Fairchild } & 1974-1975 \\ \text { John A. Clendening } & 1975-1976 \\ \text { D. Colin McGregor } & 1975-1976 \\ \text { Richard W. Hedlund (Past President) } & 1975-1976 \\ \text { Gottfried K. Guennel } & 1976-1977 \\ \text { Raymond A. Malloy } & 1976-1977 \\ \text { Kenneth M. Piel (Past President) } & 1976-1977 \\ \text { Norman O. Frederiksen } & 1977-1978 \\ \text { Evan J. Kidson } & 1977-1978 \\ \text { Richard L. Pierce* (Past President) } & 1977-1978 \\ \text { John E. Bennett } & 1978-1979 \\ \text { William C. Elsik (Past President) } & 1978-1979 \\ \text { Jocelyne A. Legault } & 1978-1979 \\ \text { * - deceased } & \end{array}$

\section{DIRECTORS-AT-LARGE}

Jonathan P. Bujak

1979-1980

Jack D. Burgess

1979-1980

Charles J. Felix*

1979-1981

Sarah P. Damassa

1979-1981

Carol A. Chmura

1980-1982

David J. McIntyre

1980-1982

Raymond A. Christopher

1981-1983

Rex Harland

1981-1983

James E. Canright

Jocelyne A. Legault

1982-1984

1982-1984

Lucy E. Edwards

1983-1985

Virgil D. Wiggins*

1983-1985

Judith K. Lentin

1984-1986

E. Reed Wicander

1984-1986

William C. Cornell

1985-1987

Barbara L. Whitney

1985-1987

Patricia G. Gensel

1986-1988

David K. Goodman

1986-1987

Harold V. Kaska

1987-1988

Robert L. Ravn

1987-1988

Loretta S. Satchell

1987-1989

Owen K. Davis

1988-1990

Stephen A. Hall

1988-1990

George F. Hart

1988-1990

Leonard E. Eames

1989-1991

Eleanora I. Robbins

1989-1991

Nairn R. Albert

1990-1992

V. Eileen Williams

1990-1992

Sarah P. Damassa

1991-1993

Arthur R. Sweet

1991-1993

Martin B. Farley

1992-1994 


\begin{tabular}{ll} 
Martin J. Head & $1992-1994$ \\
R. Farley Fleming & $1993-1995$ \\
Joyce Lucas-Clark & $1993-1995$ \\
Rosemary A. Askin & $1994-1996$ \\
Thomas D. Demchuk & $1994-1996$ \\
Donald W. Engelhardt & $1995-1997$ \\
Jocelyne A. Legault & $1995-1997$ \\
Javier Helenes-Escamilla & $1996-1998$ \\
Gretchen D. Jones & $1996-1998$ \\
Joyce Lucas-Clark & $1997-1999$ \\
Pierre A. Zippi & $1997-1999$ \\
Robert A. Cushman Jr. & $1998-2000$ \\
Paul K. Strother & $1998-2000$ \\
Sharma L. Gaponoff & $1999-2001$ \\
James B. Riding & $1999-2001$ \\
Thomas D. Davies & $2000-2002$ \\
Merrell A. Miller & $2000-2002$ \\
Peta J. Mudie & $2001-2003$ \\
Carlos A. Jaramillo & $2001-2003$ \\
Daniel Michoux & $2002-2004$ \\
Eddie B. Robertson & $2002-2004$ \\
Enrique Martinez-Hernandez & $2003-2005$ \\
Francine M. G. McCarthy & $2003-2005$ \\
Peter P. McLaughlin Jr. & $2004-2006$ \\
Jörg Pross & $2004-2006$ \\
Thomas D. Davies & $2005-2007$ \\
Sophie Warny & $2005-2007$ \\
Sarah R. de la Rue & $2006-2008$ \\
Joyce Lucas-Clark & $2006-2008$ \\
Barrie Dale & $2007-2009$ \\
Yow-Yuh Chen & $2007-2009$ \\
\hline &
\end{tabular}

APPENDIX 4 - AASP annual meetings 1968 to 2008

$\begin{array}{lll}1 & 1968 & \text { Baton Rouge, Louisiana } \\ 2 & 1969 & \text { State College, Pennsylvania } \\ 3 & 1970 & \text { Toronto, Ontario (Canada) } \\ 4 & 1971 & \text { Tucson, Arizona } \\ 5 & 1972 & \text { Newport, Rhode Island } \\ 6 & 1973 & \text { Anaheim, California } \\ 7 & 1974 & \text { Calgary, Alberta (Canada) } \\ 8 & 1975 & \text { Houston, Texas } \\ 9 & 1976 & \text { Halifax, Nova Scotia (Canada; with CIMP) } \\ 10 & 1977 & \text { Tulsa, Oklahoma } \\ 11 & 1978 & \text { Phoenix, Arizona } \\ 12 & 1979 & \text { Dallas, Texas } \\ 13 & 1980 & \text { Keystone, Colorado } \\ 14 & 1981 & \text { New Orleans, Louisiana } \\ 15 & 1982 & \text { Dublin (Ireland; with CIMP) }\end{array}$




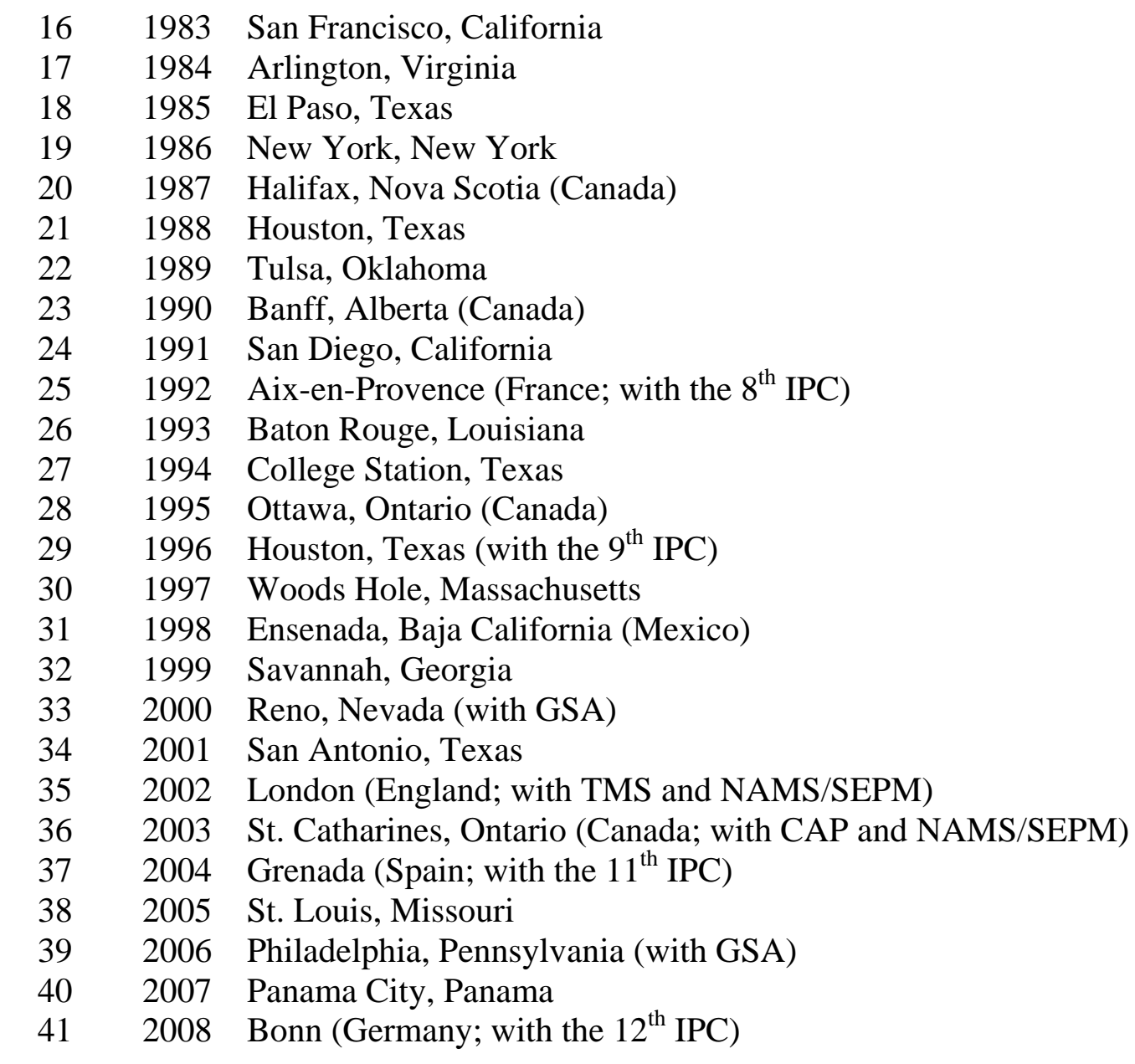

\section{Text-Figure captions:}

Text-Figure 1. Membership totals for AASP; the numbers are consolidated, and not subdivided into individual and institutional categories. These data were gathered from past AASP Newsletters and Secretary-Treasurer's reports. Gaps in the record exist where no reports on membership numbers are available.

Text-Figure 2. The total financial assets of AASP. These data were gathered from past AASP Newsletters and Secretary-Treasurer's reports. Gaps in the record exist where no reports on assets are available.

Text-Figure 3. The numbers of biostratigraphers (i.e. micropaleontologists and palynologists) employed by the energy industry from 1975 to 1998, taken from J. M. Armentrout (unpublished information 1998).

Text-Figure 4. The distribution of AASP individual members for 2008 from each major geographic area.

\section{Plate caption:}

\section{PLATE 1}


A gathering of 11 past Presidents of AASP taken on Wednesday October $8^{\text {th }} 2003$ during the $36^{\text {th }}$ Annual Meeting at St. Catherines, Ontario, Canada. Back row, from left to right: John H. Wrenn*; Fredrick J. Rich; Douglas J. Nichols; David T. Pocknall; E. Reed Wicander; and James B. Riding. Front row: Geoffrey Norris; Jan Jansonius; Alfred Traverse; Robert T. Clarke; and Don G. Benson Jr. (* - now deceased). The photograph was taken by another past president, Vaughn M. Bryant Jr.

\section{BIOPICS:}

THOMAS D. DEMCHUK is a palynologist/stratigrapher with ConocoPhillips Limited, based in Houston, Texas. He has worked in the petroleum industry for over 16 years, initiating his career with the Amoco Corporation in the early 1990's. His specialities include Cenozoic palynostratigraphy, particularly pollen and spores, but also including dinoflagellate cysts and calcareous microbiotas. As part of his numerous projects he also has a good working knowledge of Mesozoic palynology, particularly as it applies to the North Sea. Other areas of geographic interest include Canada (Western Interior and the Arctic), west Africa, and southeast Asia. His primary duties include the chronostratigraphic applications of palynofloras, and paleoenvironmental/paleobathymetric investigations integrated with exploration and other stratigraphic data. Thomas started his palynology studies at the University of Alberta, Edmonton, Canada (his hometown, Go Oilers!), where he completed his MSc in Paleocene stratigraphy. He then continued with his $\mathrm{PhD}$ at the University of Calgary, Canada, conducting research on the palynology and organic petrology of Paleogene coals. Upon the completion of his doctorate, he moved to Houston to begin his career in the petroleum industry. He has served AASP as a Director-at-Large from 1995-1996, and has been AASP Secretary-Treasurer since 1999. Recently he has been added to the AASP Editorial Board.

JAMES B. RIDING is a palynologist/stratigrapher with the British Geological Survey based in Nottingham, England. Jim was recently awarded Individual Merit status to work on a project entitled 'Global Jurassic dinoflagellate cyst palaeobiology and its applications'. He has over 25 years experience in Mesozoic-Cenozoic palynology. In the 1980s, Jim worked mainly on the the Mesozoic palynology of onshore and offshore UK, principally the North Sea. His current interests presently include the palynology of Europe, Australasia, Antarctica, west Africa, the Americas, Russia, and the Middle East, together with palynomorph provincialism, forensic palynology, paleoenvironmental palynology, palynomorph preparation techniques, and the morphology, systematics and taxonomy of dinoflagellate cysts. Jim studied geology at the University of Leicester, before pursuing palynology by studying the famous MSc course at the University of Sheffield. He left Sheffield for BGS, where he received a $\mathrm{PhD}$ from the University of Sheffield for a thesis on the Jurassic dinoflagellate cyst floras of northern and eastern England. The British Antarctic Survey have used Jim as a consultant palynologist and he has visited the Antarctic Peninsula for fieldwork tours during the Austral summers of 1989 and 2006. The most recent field season was spent on Seymour Island. He undertook a secondment to Geoscience Australia in Canberra, Australia in 1999-2000, where he worked on the taxonomy of Australian Jurassic dinoflagellate cysts with Robin Helby and Clinton Foster. Jim was awarded a DSc by the University of Leicester in 2003. He served as a Director-at-Large of 
AASP between 1999 and 2001, was President in 2003, and became Managing Editor in 2004. 